\title{
ALTERATIONS OF ANTIOXIDANT ENZYMES DURING ALLOXAN-INDUCED DIABETES
} (EXPERIMENTAL STUDY)

Tbilisi State Medical University

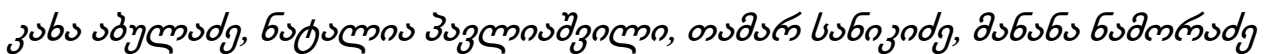

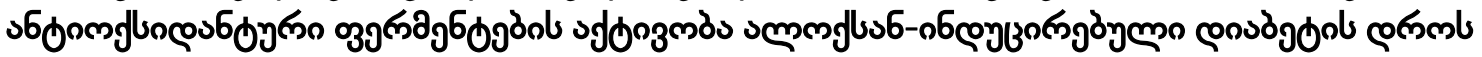

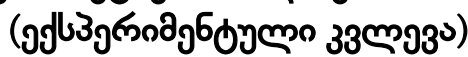

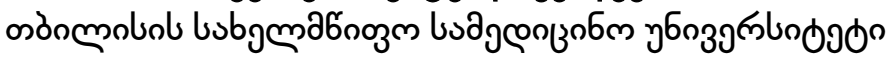

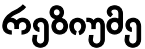

h

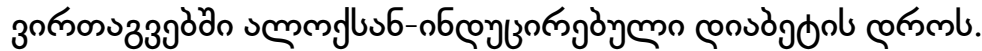

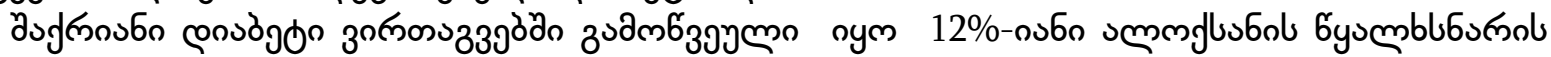

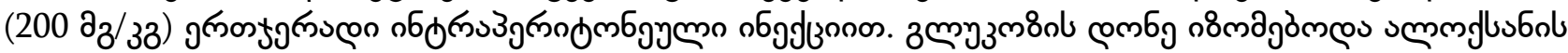

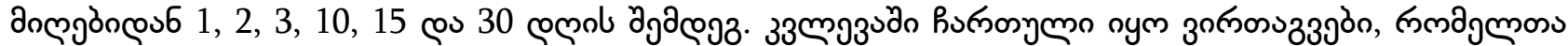

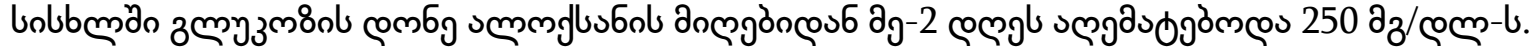

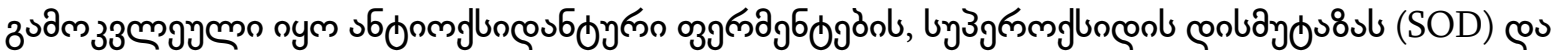
3०0

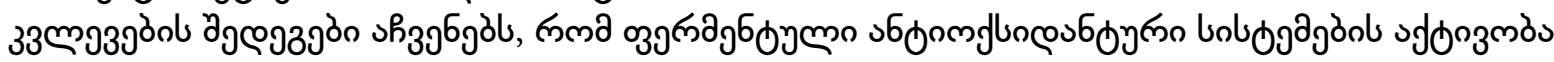

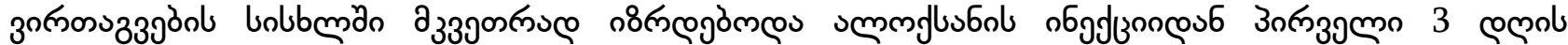

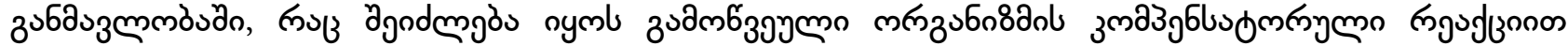

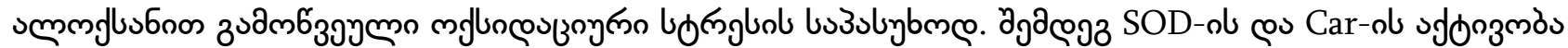

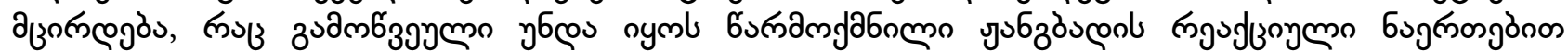

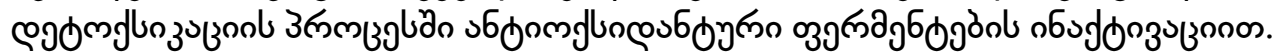

INTRODUCTION. During Diabetes Mellitus (DM) oxidative stress intensification is commonly detected $(1,2,3)$. Excessive formation of reactive oxygen species results in alteration of cells' functions and metabolism, which in turn, can cause organs dysfunction [4]. Our study aimed to assess blood antioxidant system activity in the animal model, particularly rats with alloxan-induced diabetes mellitus.

MATERIAL AND METHODS. A total of sixty Wistar male rats (280-350 g) were used in our study. The animals were cared for and used under the Laboratory Animal Research (ILAR) guidelines for the care and use of animals in experimental studies. The rats were housed in a well-ventilated room under standard laboratory conditions (12:12 h dark/light cycle). They were allowed to acclimatize for 3 weeks, during which they had free access to a commercial pellet diet and water ad libitum. All the procedures held on the rats were approved by the Animal Care and Use Committee of the Tbilisi State Medical University.

After the acclimatization period, diabetes mellitus was induced in the rats by a single intraperitoneally injection of freshly prepared $12 \%$ aqueous alloxan solution (at a dose of $200 \mathrm{mg} / \mathrm{kg}$ ). Control rats (control group of 6 rats) received a similar volume of normal saline. The glucose level was measured after 1, 2, 3, 10, 15, and 30 days of alloxan administration. The study included those rats with blood glucose levels above $250 \mathrm{mg} / \mathrm{dl}$ on the 2 nd day after alloxan administration (90\% of the total amount of animals; an experimental group of 54 rats).

We investigated the activity of antioxidant enzymes, superoxide dismutase (SOD) and catalase (Cat) in blood serum.

The blood was centrifuged at 2,000g for $10 \mathrm{~min}$. The blood serum was separated in the nonheparinized tube for serum collection and the activity of antioxidant enzymes, Cat, and SOD was determined with standard methods by spectrophotometry with ELISA Microplate Reader (Bio Tek Instruments, Inc, USA). The activity of SOD was determined by absorbance at $450 \mathrm{~nm}$, while the activity of Cat was measured at $570 \mathrm{~nm}$. 
Statistical analysis of obtained results was performed by the use of the SPSS statistical analysis program package (version 10.0). The average parameters and their statistical derivations were analyzed. The difference between groups was evaluated by Student's t-test. In all cases, statistical significance was obtained at $\mathrm{P}<0.05$.

RESULTS. On the 2nd day of alloxan administration, the blood glucose level in rats from the experimental group increased by $150 \%$. On the 3rd day of observation, its level reached the maximum $275 \%$ from the control level, after that, it began to decrease and on the 30th day of observation reached the control level (Fig. 1).

Figure 1. Dynamics of blood glucose indices in rats in the model of alloxan-induced diabetes

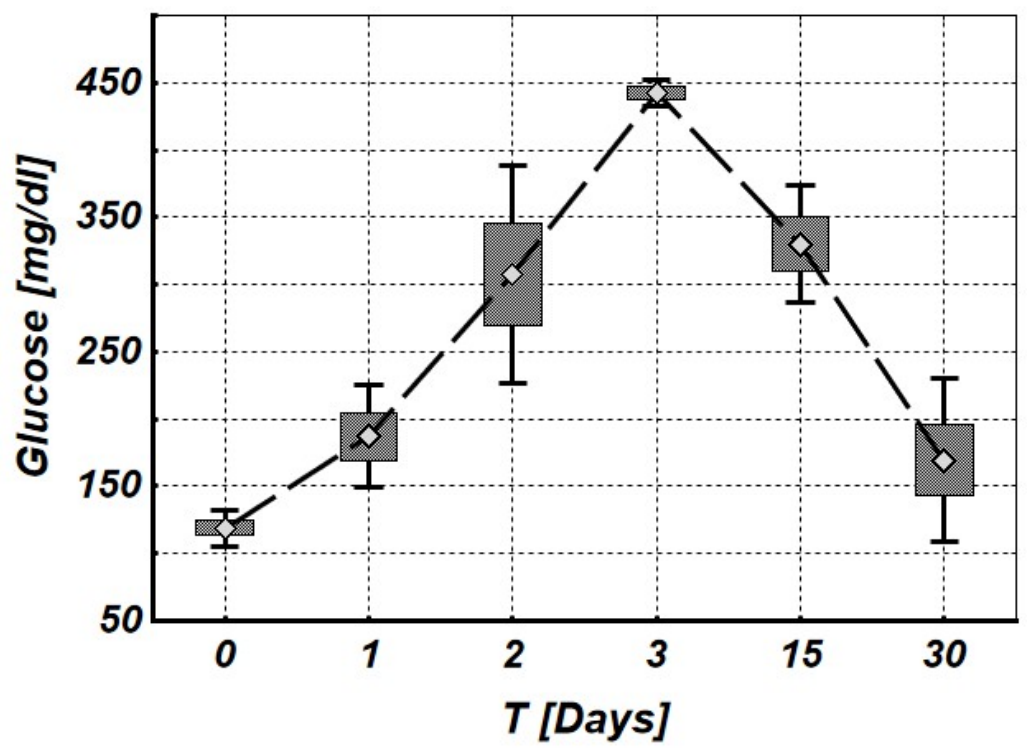

The dynamics of enzymatic and non-enzymatic antioxidant systems activity in the experimental rats' blood with alloxan-induced diabetes mellitus showed that on the 3rd day after the alloxan administration the activity of SOD increased by $117 \%$ (Fig.2A), while the activity of Cat increased by $45 \%$ (Fig. 2B) compared to the control level. On the 15th day of observation, the activity of SOD slightly decreased, while the activity of Cat continued to increase and reached a maximum value $-181 \%$ of control level, afterwards, it began to decrease. At the end of observation (30th day), the activity of SOD and Cat returned to the initial level (Fig. 2A, B).

Figure 2. Dynamics of blood SOD (A) and Cat (B) activity in rats in the model of alloxan-induced diabetes

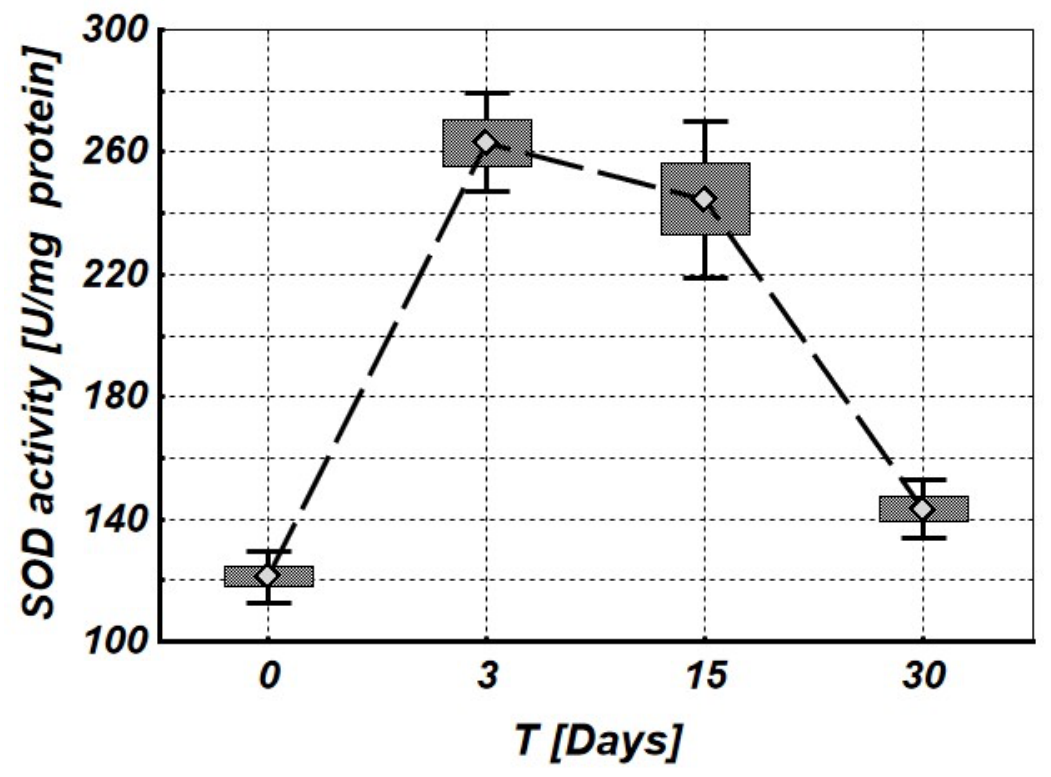




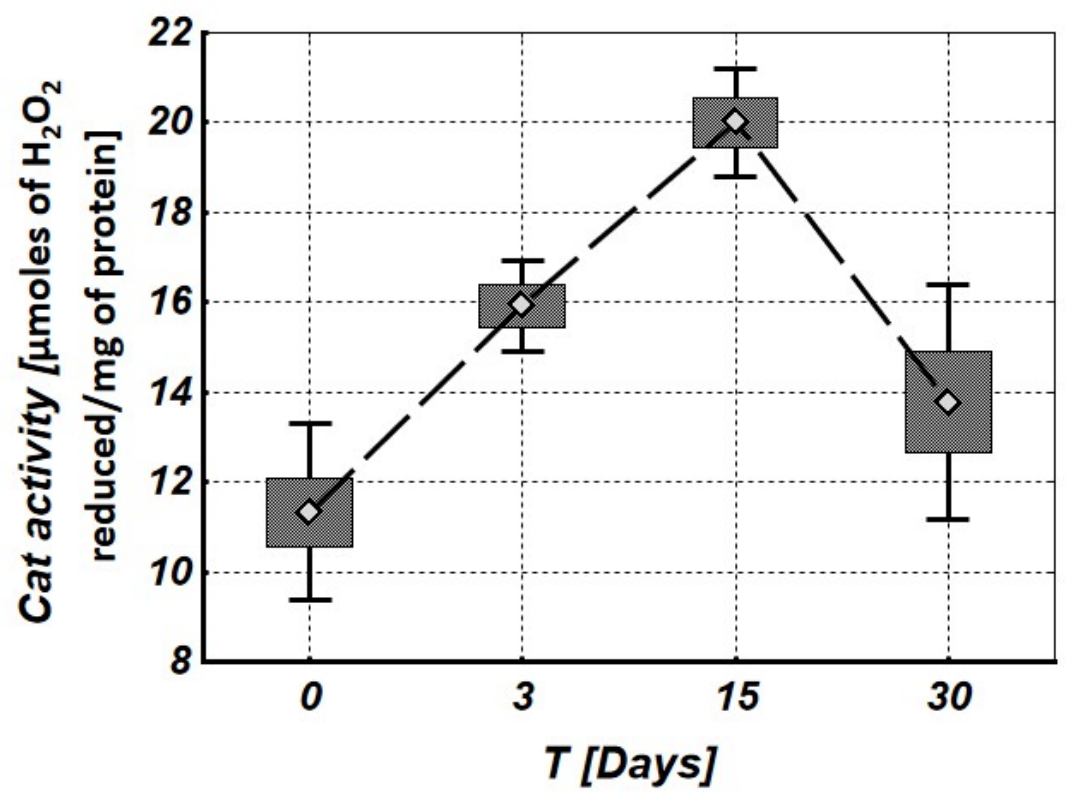

B

SOD, Cat activity in blood in the control rats did not change during the entire observation period (30 days) (data not shown).

DISCUSSION. At the oxidative stress conditions, antioxidant proteins/enzymes glycation, and disturbances in micronutrient status in DM antioxidant defence mechanisms are often observed [5, 6].

Specialized enzymatic (Cat, SOD, thioredoxin reductase (TrxR), and enzymes involved in glutathione metabolism (glutathione peroxidase (GPx), glutathione reductase (GR)), as well as numerous non-enzymatic antioxidant systems, prevent the formation of too high free radical concentrations and the development of oxidative stress conditions in eukaryotic organisms' cells. Studies indicate alterations of antioxidant enzymes (SOD, Cat, etc.) activity in different tissues during DM [7]. According to the results of our study, the activity of enzymatic antioxidant systems in rats' blood sharply increased during the first three days after injection of alloxan, which may be the result of the compensatory reaction of the body in response to alloxan-induced oxidative stress. Subsequently, an excess amount of superoxide radicals possibly reduced the activity of SOD (15-30th days), later (after 15 days of the observation) hydrogen peroxide, formed as a result of the detoxification of superoxide radicals, inhibits Cat activity (Fig. 2A, B). The decreased activity of the enzymatic antioxidant system at the later stages of alloxan-induced diabetes mellitus in rats may be due to the utilization of antioxidant proteins in the detoxification process of ROSs, their glycation, and decreased level of protein synthesis in the body at the intensive hyperglycemia and oxidative stress conditions.

The study results confirm the incontrovertibility of the critical role of oxidative stress in the pathophysiology of DM. The suppression and/or scavenging of intracellular free radical species provide amelioration of intensity of oxidative stress and prevention of ensuing pathologic complications associated with DM.

\section{References:}

1. Mrowicka M. The role of disorders of the prooxidant-antioxidant system in diabetes etiopathology. Postepy Hig Med Dosw (Online) 2011; 16, 65:534-41.

2. Asmat U, Abad K, Ismail K. Diabetes mellitus and oxidative stress - A concise review. Saudi Pharm J. 2016; 24(5): 547-553.

3. Sharma VK, Kumar S, Patel HJ, Hugar S. Hypoglycemic activity of Ficus glomerata in alloxan-induced diabetic rats. International Journal of Pharmaceutical Sciences Review and Research 2010; 1(2):18-22.

4. Giacco F, Brownlee M. Oxidative stress and diabetic complications. Circ Res. 2010; 107(9): 1058-1070.

5. Bajaj S, Khan A. Antioxidants and diabetes. Indian J. Endocrinol. Metab. 2012; 16: S267-S271. 
6. Yuan Y, Jiao X., Lau WB, Wang Y, Christopher TA, Lopez BL, Lopez BL, RamachandraRao SP, $\underline{\text { Tao }}$ L, $\underline{\text { Ma }}$ $\mathrm{X}$-L. Thioredoxin glycation: A novel posttranslational modification that inhibits its antioxidant and organ protective actions. Free Radical Biol. Med. 2010; 49: 332-338.

7. Ojiako AO, Chikezie PC, Ogbuji CA. Renal and hepatic antioxidant status of hyperglycemic rats treated with single and combinatorial herbal formulations. Pharmacogn.Commun. 2015; 5: 148-159.

КАХА АБУЛАДЗЕ, НАТАЛЬЯ ПАВЛИАШВИЛИ, ТАМАР САНИКИДЗЕ,

МАНАНА НАМОРАДЗЕ

ИЗМЕНЕНИЯ АНТИОКСИДАНТНЫХ ФЕРМЕНТОВ ПРИ АЛЛОКСАН-ИНДУЦИРОВАННОМ ДИАБЕТЕ (ЭКСПЕРИМЕНТАЛЬНОЕ ИССЛЕДОВАНИЕ)

Тбилисский Государственный Медицинский Университет

\section{PEЗЮME}

Наше исследование было направлено на оценку активности антиоксидантной системы крови на животной модели аллоксан-индуцированного диабета у крыс.

Диабет у крыс вызывали однократным внутрибрюшинным введением свежеприготовленного 12\% водного раствора аллоксана (200 мг / кг). Уровень глюкозы измеряли через 1, 2, 3, 10, 15 и 30 дней после введения аллоксана. В исследование были включены только крысы с уровнем глюкозы в крови выше 250 мг / дл на 2-й день после введения аллоксана.

Мы исследовали активность антиоксидантных ферментов супероксиддисмутазы (СОД) и каталазы (Cat) в сыворотке крови.

Результаты исследований показывают, что активность ферментативных антиоксидантных систем в крови крыс резко возрастает в первые 3 дня после введения аллоксана. Это может быть связано с компенсаторной реакцией организма в ответ на оксидативный стресс, вызванный аллоксаном. Впоследствии активность СОД и Кэт снизилась, что может быть связано с использованием антиоксидантных белков в процессе детоксикации АФК, их гликированием и снижением уровня синтеза белка в организме в условиях интенсивной гипергликемии и окислительного стресса.

\section{KAKHA ABULADZE, NATALIA PAVLIASHVILI, TAMAR SANIKIDZE,} MANANA NAMORADZE

\section{ALTERATIONS OF ANTIOXIDANT ENZYMES DURING ALLOXAN-INDUCED DIABETES (EXPERIMENTAL STUDY) \\ Tbilisi State Medical University}

\section{SUMMARY}

Our study aimed to assess the activity of the blood antioxidant system in the animal model of alloxan-induced diabetes in rats.

Diabetes in rats was induced diabetes by a single intraperitoneally injection of freshly prepared $12 \%$ aqueous alloxan solution ( $200 \mathrm{mg} / \mathrm{kg}$ ). The glucose level was measured after 1, 2, 3, 10, 15, and 30 days from alloxan administration. The study included only those rats with blood glucose levels above $250 \mathrm{mg} / \mathrm{dl}$ on the 2nd day after alloxan administration.

We investigated the activity of antioxidant enzymes, superoxide dismutase (SOD) and catalase (Cat) in the blood serum.

The results of the studies show that the activity of enzymatic antioxidant systems in rats' blood sharply increased during the first 3 days after injection of alloxan. That may be due to the compensatory reaction of the body in response to alloxan-induced oxidative stress. Afterwards, the activity of SOD and Cat decreased, which may be due to the utilization of antioxidant proteins in the detoxification process of ROSs, their glycation and decreased level of the protein synthesis in the body at the intensive hyperglycemia and oxidative stress conditions. 